DEPARTMENT OF THE INTERIOR

UNITED STATES GEOLOGICAL SURVEY

GEOLOGIC MAP OF THE BLACK MOUNTAIN QUADRANGLE, PINAL COUNTY, ARIZONA

\author{
By Medora H. Krieger
}




\title{
GEOLOGIC MAP OF THE BLACK MOUNTAIN QUADRANGLE, ARIZONA
}

\author{
By Medora H. Krieger
}

\section{REGIONAL GEOLOGIC SETTING}

The broad regional geologic and structural setting of the Winkelman 15-minute quadrangle, of which the Black Mountain quadrangle is the southwest part, is discussed by Krieger (1974). Rocks within the area range from Precambrian to Holocene in age. Many of the units, however, are not now present in the Black Mountain quadrangle, and because of this, the geologic features appear structurally less complex than in the adjacent areas.

\section{STRATIGRAPHY}

The oldest Precambrian rocks in the area of the larger scale index map are the Pinal Schist and intrusive rocks, largely the Ruin Granite (Oracle Granite of N.P. Peterson, 1938). Batholithic masses of Ruin Granite (1,430 m.y.) were intruded after a period of intense deformation that produced near-vertical east-trending foliation and bedding in the schist. The schist and granite are overlain with profound angular unconformity by Precambrian sedimentary rocks--the Apache Group and the disconformably overlying Troy Quartzite. Diabase, about 1,200 m.y. old (Silver, 1960; Damon and others, 1962), forms sills in the Apache Group and Troy Quartzite, sill-like masses in the schist and granite generally parallel to, and not more than 500 feet below, the pre-Apache surface (Shride, 1967, p. 56), and some dikes. The sills inflated but did not perceptibly tilt the Precambrian sedimentary rocks.

After a long period of erosion, Paleozoic formations were deposited paraconformably on the Precambrian sedimentary rocks. Both the Precambrian and Paleozoic sedimentary rocks have been completely stripped from the Black Mountain quadrangle.

Remnants of volcanic and sedimentary rocks, the Cloudburst Formation of Late Cretaceous age, occur in the southeastern part of the quadrangle as a thin sheet of near-vertical units emplaced by gravity sliding. Late Cretaceous diorite and Late Cretaceous and(or) early Tertiary porphyry masses intrude the Precambrian granite; aplite intrudes the diorite.

Cenozoic stratigraphy in eastern Pinal County has recently been revised by Krieger and others (1973). In the areas of the larger scale index map Miocene and Pliocene sedimentary deposits, formerly called the Gila Conglomerate or Group, are now divided into three formations. In addition, Pleistocene and Holocene alluvial deposits, also formerly included in the Gila Conglomerate or Group, overlie these formations. None of the Miocene or Pliocene formations have been recognized in the area of the Black Mountain quadrangle.

\section{STRUCTURF:}

The major structural features in the Winkelman 15minute quadrangle are high-angle faults and northnorthwest-trending en echelon ridges of steeply dipping to overturned Precambrian sedimentary rocks and diabase and, locally, Paleozoic rocks. As the tops of the beds in these ridges always face east, the structures are interpreted as partly eroded roots of a single monoclinal structure, or possibly a series of monoclinal structures. Locally, the section within an individual ridge is repeated along what appear on a map as high-angle faults but which are inferred to be tilted thrusts. Because the Paleozoic and Precambrian sedimentary rocks have been completely stripped from the area of the Black Mountain quadrangle, the only hint of these structures is the long north-trending dike-like masses of diabase in granite. Although they appear to have been intruded well below the erosion surface on which the sedimentary rocks were deposited, they are inferred to have been intruded as sill-like masses that were intruded not more than $500 \mathrm{ft}$. below the pre-sedimentary surface and later separated by faulting. The gravity slides that floor the Cloudburst Formation in the Black Mountain quadrangle may predate, or they may be related to post-early(?) Miocene gravity slides in the Putnam Wash quadrangle.

\section{MINERALIZATION}

The Winkelman 15-minute quadrangle, whose southwest one-quarter is the Black Mountain 7-1/2-minute quadrangle, is adjacent to three major copper deposits: the San Manuel to the southeast, the Christmas to the northeast, and the Ray to the northwest. Little evidence of mineralization was observed in the Black Mountain quadrangle. The mineralization is mostly associated with quartz veins in the Ruin Granite and locally in shear zones in the Cretaceous diorite.

\section{DESCRIPTION OF MAP UNITS}

\section{SURFICIAL DEPOSITS}

Alluvium (0-15 ft exposed).-Flood-plain deposits along valley bottoms, composed of clay, silt, sand, and some gravel, largely unconsolidated

Talus deposits (0 - about $20 \mathrm{ft}$ exposed).-Veneer of rock debris derived from Pinal Schist; only deposits in sec, 27 , T. 7 S., R. 13 E. are large enough to map.

. Soil and gravel veneer on pediments and younger terraces $(0.25 \mathrm{ft})$. - Subangular pebbles and cobbles in a generally reddish-brown, fine- to coarse-grained matrix. Includes alluvium in valley bottoms, colluvium on slopes, and small unmapped exposures of granitic bedrock and of gravel and sand of Pleistocene age older than the pediment soils, especially in northwest corner of map area. The dark-red-brown soils were developed during one of the pre-Wisconson interglaciations.

Undifferentiated gravels.-Soil and gravel on pediments and terraces, talus, and alluvium; includes isolated exposures of older gravels and granite. 


\section{SAND AND GRAVEL (AT LEAST 200 FT)}

Poorly exposed, essentially unconsolidated gravel and sand along eastern and western edges of the quadrangle. Deposits in eastern part are composed largely of granitic rocks. Those in western part also contain abundant clasts derived from Pinal Schist, diorite gneiss, and, in northwest part, from the Cretaceous diorite. Isolated i, exposures with steeper dips may be older gravels.

DIKES

Quartz latite or rhyolite porphyry.-Rhyolite to quartz latite in composition. White to very light gray, very fine grained (probably originally aphanitic to glassy); with widely scattered phenocrysts (1-2 $\mathrm{mm}$ in diameter) of sericitized sanidine, making up perhaps 10 percent of the rock, less common quartz, in a groundmass of quartz, K-feldspar, sericite, and goethite or limonite specks. Age unknown, but rock does not resemble the less altered Miocene rhyolite dikes in the Putnam Wash quadrangle (Krieger, 1974d). Tentatively correlated with the younger quartz latite porphyry of Late Cretaceous and (or) early Tertiary age in the Crozier Peak quadrangle (Krieger, 1974b).

Aplite-Light-colored aplitic to pegmatitic dikes intruding diorite. Some of the aplite mapped as Precambrian may be in this group:

Hornblende porphyry. - Fine-grained rocks that range from andesite to melanocratic rhyodacite. Mostly oliveto greenish-gray, porphyritic to nonporphyritic rocks with needie-like laths of hornblende from slightly larger than groundmass size to rarely $2 \mathrm{~mm}$ long. Numerous very small unmapped dikes of this sort intrude Ruin Granite east and south of Black Mountain.

Rhyodacite porphyry.-Light-olive-gray and pale-olive to dusky-yellow rhyodacite porphyry. About 20 to 30 percent of rock is composed of altered plagioclase from 3 to $9 \mathrm{~mm}$ long. Altered euhedral hornblende and biotite phenocrysts: from 1 to $2 \mathrm{~mm}$ long make up about 10 percent of the rock. The groundmass is aphanitic and altered:

DIORITE

Medium-dark-gray, fine- to coarse-grained; composed of plagioclase laths (zoned and locally sericitized), biotite, hornblende, magnetite, some pyroxene, and a little quartz. Some of the mafic minerals are altered to chlorite, epidote, and magnetite. Two small masses, near the south edge of sec. 32 , T. 7 S., R. 14 E., are tentatively included in the diorite. Tentatively correlated with diorite in the Winkelman $7 \frac{1}{2} 2$ minute and Crozier Peak quadrangles.

CLOUDBURST FORMATION $(6,500$ FT. EXPOSED, IF NOT DUPLICATED BY FAULTING)

Named by Pelletier (1957; see also Creasey, 1965, 1967). Mafic volcanic rocks of probable latitic composition and interbedded fanglomerate and megabreccia crop out in the southeast corner of the map area and are the northern tip of a larger unmapped mass. The Cloudburst Formation is included in the Late Cretaceous because Creasey $(1965,1967)$ considered it probably the same age as the volcanic rocks (Williamson Canyon Volcanics) in the Christmas quadrangle. These volcanic rocks were considered Late Cretaceous by Willden (1964) and Late Cretaceous and(or) early Tertiary by Creasey $(1965,1967)$. In the Crozier Peak quadrangle the Williamson Canyon Volcanics is intruded by diorite that in the Winkelman quadrangle is dated at 65 m.y. (Late Cretaceous)

Volcanic rocks. - Andesitic(?) and possibly latitic flows and flow breccias; the larger mass (secs. 3, 4, 9, 10, T. 8 S., R. 14 E.) consists mostly of flows to the west and of breccias with some interbedded volcanic conglomerate to the east. Flows are vesicular to amygdaloidal, grayish- to blackish-red and grayish-red-purple rocks with altered mafic phenocrysts, mostly less than $2 \mathrm{~mm}$ long.

Fanglomerate. - Subangular to subrounded pebbles to small: boulders derived from volcanic rocks of the Cloudburst Formation, Ruin Granite, and locally some nongranitic clasts, including Pinal Schist and Apache Group, in a :dark-reddish matrix.

Megabreccias.-Small lenses of megabreccia, 200 to $1,500 \mathrm{ft}$ long and 50 to 300 'ft wide, composed of a single rock type in an individual lens. Fragments are angular and mostly less than 2 . ft long, in a finely comminuted matrix of the same material as the fragments. Ratio of fragments to 'matrix is high. Breccias of quartzite and granite are very well indurated.

DIABASE

Mostly dikelike masses of dark-gray to greenish-gray or olive-gray, fine- to coarse-grained rock with diabasic to ophitic texture. Composed of plagioclase, pyroxene, olivine, magnetite, and ilmentite. Felsic dikes with hornblende needles, probably a differentiate of the diabase, in the SW $1 / 4$ sec. 32 , T. 6 S., R. 14 E. As most Precambrian diabase occurs as sills in, or slightly below the base of, the Apache Group, and as no Apache Group rocks are present in this quadrangle, correlation of these rocks with Precambrian diabase was originally questioned. Although the $\mathrm{SiO}_{2}$ content is higher and the $\mathrm{TiO}_{2}$ content lower than in known Precambrian diabase in the Salt River Canyon area (A.F. Shride, written communication, 1965), these constituents are present in amounts similar to content in known Precambrian diabase in the Brandenburg Mountain quadrangle (table 1). The diabase, therefore, is considered Precambrian; its present distribution may be due to unrecognized faults. The only faults suggested are the strands of Ripsey Wash tilted thrust (Krieger, 1974b, 1974).

Troy Quartzite.-Present only as megabreccia (Kbt) in the Cloudburst Formation, where it was derived from white to light-gray, thin- to thick-bedded feldspathic to nonfeldspathic quartzite.

\section{APLITE}

Includes some muscovite granite and pegmatite; occurs as dikes and larger irregular masses. Many large areas are mixed zones of Ruin Granite, muscovite granite, and (or) aplite, with indefinite contacts against the Ruin. Granite. Aplite dikes adjacent to rhyolite or quartz latite dikes on the east side of the Black Mountain are fine-grained granite with an aplitic texture and and with both muscovite and biotite. Some aplite is related to the Ruin Granite and some to the muscovite granite (see details of muscovite granite, Krieger, 1974d). Other aplites that have been shown as Precambrian, however, may be Late Cretaceous and(or) early Tertiary. RUIN GRANITE

Named by Ransome (1903); same as Oracle Granite of N.P. Peterson (1938). Coarse-grained, porphyritic, pinkish- to yellowish-gray quartz monzonite, speckled with dark biotite books as large as $5 \mathrm{~mm}$ and containing euhedral, somewhat poikilitic and perthitic phenocrysts of inicrocline and microperthite, as large as $4 \times 2 \mathrm{~cm}$, locally largèr; somewhat zoned plagioclase, mostly less than $1 \mathrm{~cm}$, locally $3 \mathrm{~cm}$, much of it sericitized; quartz as rounded crystals, about $6 \mathrm{~mm}$, and as finer inter- 
growths with microcline; accessory magnetite and apatite; biotite locally altered to a mixture of magnetite and chlorite. Intrudes Pinal Schist. According to Silver (1968), the age of granite (quartz monzonite) in Arizona based on $\mathrm{U}-\mathrm{Pb}$ isotope systems in zircon is $1,430-1,460$ m.y.; biotite from the Ruin Granite near Oracle gave an age of $1,420 \mathrm{~m} . \mathrm{y}$. by the K-Ar method, according to Damon and others (1962). (See also discussion of age of Ruin Granite and muscovite granite in Krieger, 1974d.)

TABLE 1-Chemical and normative compositions of diabase.

[Analyses W-99 and A-11 under the direction of Leonard Shapiro, methods given in U.S. Geol. Survey Bull. 1144A; Y-19-64 by C.L. Parker, methods given in U.S. Geol. Survey Bull. 1170

\begin{tabular}{|c|c|c|c|c|c|c|c|}
\hline \multirow{2}{*}{\multicolumn{4}{|c|}{$\begin{array}{c}\frac{\text { Field No.W-99 A-11 Y-19-64 }}{\text { Chemical composition }} \\
\text { (in percent) }\end{array}$}} & \multicolumn{4}{|c|}{ W-99 A-11 Y-19-64 } \\
\hline & & & & \multicolumn{4}{|c|}{ CIPW norms (wt. percent) } \\
\hline$\overline{\mathrm{SiO}_{2}}$ & 50.9 & 49.2 & 45.50 & Q & 0.5 & $-\cdots$ & $\ldots$ \\
\hline $\mathrm{l}_{2} \mathrm{O}_{3}$ & 14.5 & 15.9 & 16.69 & or & 7.3 & 5.5 & 10.5 \\
\hline $\mathrm{e}_{2} \mathrm{O}_{3}$ & 1.6 & 2.5 & 2.45 & $a b$ & 21.7 & 23.2 & 26.4 \\
\hline 0 & 9.6 & 8.8 & 10.48 & an & 25.4 & 29.1 & 27.8 \\
\hline g0 & 6.4 & 6.9 & 6.07 & Wo & 8.5 & 7. & 2.7 \\
\hline 0 & 9.4 & 9.7 & 7.28 & en & 16.3 & 12.8 & 1.9 \\
\hline $\mathrm{a}_{2} 0$ & 2.5 & 2.7 & 3.02 & fs & 15.2 & $y$ & 1.6 \\
\hline $\mathrm{K}_{2} \mathrm{O}$ & 1.2 & .91 & 1.72 & fo & -- & 3.3 & 9.6 \\
\hline $\mathrm{H}_{2} \mathrm{O}$ & .25 & .19 & 25 & fa & --- & 2.6 & 9.1 \\
\hline $0+$ & 1.9 & .81 & 2.90 & $\mathrm{mt}$ & 2.4 & 3.7 & 3.7 \\
\hline $\mathrm{TiO}_{2}$ & 1.1 & 1.3 & 2.79 & $\mathrm{hm}$ & -- & -- & -- \\
\hline $\mathrm{P}_{2} \mathrm{O}_{5}$ & .15 & .20 & .44 & il & 2.1 & 2.5 & 5.5 \\
\hline no & .19 & .17 & .19 & ap & .4 & .5 & 1.1 \\
\hline $\mathrm{CO}_{2}$ & .16 & $<.05$ & .01 & $\mathrm{cc}$ & .4 & $-\cdots$ & .02 \\
\hline $\mathrm{Cl}$ & --- & --- & .19 & \multicolumn{4}{|c|}{ Total $^{1} 100.20100 .0099 .92$} \\
\hline $\mathrm{F}$ & $-\cdots$ & --- & .05 & \multirow{2}{*}{$\begin{array}{l}\text { Salic } \\
\text { Femic }\end{array}$} & \multirow{2}{*}{\multicolumn{2}{|c|}{$\begin{array}{ll}54.8 & 57.7 \\
45.2 & 42.2\end{array}$}} & 64.8 \\
\hline \multirow{2}{*}{$\begin{array}{l}\text { Sub total } \\
\text { Less } 0\end{array}$} & $1+-$ & ---1 & 0.03 & & & & 35.2 \\
\hline & $\cdots$ & -- & .06 & \multirow{2}{*}{\multicolumn{4}{|c|}{$\begin{array}{l}{ }^{1} \text { In calculating the norms, } \\
\text { both } \mathrm{H}_{2} \mathrm{O}+\text { and } \mathrm{H}_{2} \mathrm{O}- \\
\text { were omitted }\end{array}$}} \\
\hline Total & 100 & & 99.97 & & & & \\
\hline
\end{tabular}

W-99 - Black Mountain quadrangle, Bloodsucker Wash, SW $1 \frac{1}{4}$ sec. 22 , T. 7 S., R. 14. E.

A-11 - Younger sill, $12 \mathrm{ft}$ above base, west side of Aravaipa Canyon, southeast of Brandenburg Mountain, Brandenburg Mountain quadrangle; data from C.T. Wrucke (written commun., 1970).

Y-19-64 - Chilled border, lower contact of 780-foot sill, Gila County; data from A.F. Shrider (written commun., 1968).

\section{DIORITE GNEISS}

A hybrid gneiss; fine- to medium-grained, nearly white and olive-gray, sheared and foliated to cataclastic gneiss and augen gneiss. Composed of plagioclase, biotite, chlorite, epidote, quartz, opaque minerals, and sphene. Probably mostly Ruin Granite contaminated with some Pinal Schist north of Rincon Ranch and Pinal Schist with some granite southwest of the Ranch. PINAL SCHIST

Named by Ransome (1903). Character of original sedimentary and volcanic(?) rocks uncertain because of subsequent injection by granite, aplite, and vein quartz, preceded or followed by shearing. Much of the Pinal is a medium-light-gray schist, augen gneiss, migmatite, and locally a spotted schist. Some light-colored layers, lenses, and augen are of granitic material, but many are of quartz grains, some of which may represent original sandy beds and lenses; some probably is a quartz porphyry with 5-10 $\mathrm{mm}$ euhedral, somewhat strained quartz phenocrysts. Some probably was a conglomerate with 1-4 $\mathrm{cm}$ quartz and (or) quartzite pebbles. The matrix in most of these rocks is fine-grained and composed of quartz and sericite with or without biotite or chlorite and some epidote and calcite. Magnetite metacrysts(?) $(3 \mathrm{~mm})$ and biotite and muscovite metacrysts $(5 \mathrm{~mm})$ are common.

\section{REFERENCES}

Cornwall, H.R., Banks, N.G., and Phillips, C.H., 1971 Geologic map of the Sonora quadrangle, Pinal and Gila Counties, Arizona: U.S. Geol. Survey Geol. Quad. Map GQ-1021, scale 1:24,000.

Cornwall, H. R., and Krieger, M. H., in preparation, Geologic map of the Kearny quadrangle, Pinal County, Arizona: U.S. Geol. Survey Geol. Quad. Map GQ-1188, scale 1:24,000.

Creasey, S.C., 1965, Geology of the San Manuel area, Pinal County, Ariz.: U.S. Geol. Survey Prof. Paper $471,64 \mathrm{p}$.

1967, General geology of the Mammoth quadrangle, Pinal County, Arizona: U.S. Geol. Survey Bull. $1218,94 \mathrm{p}$.

Damon, P.E., Livingston, D.E., and Erickson, R.C., 1962, New K-Ar dates for the Precambrian of Pinal, Gila, Yavapai, and Coconino Counties, Arizona, in New Mexico Geol. Soc. Guidebook, 13 th Field Conf., Mogollon Rim Region, east-central Arizona, p. 56-67.

Krieger, M.H., 1968a, Geologic map of the Brandenburg Mountain quadrangle, Pinal County, Arizona: U.S. Geol. Survey Geol. Quad. Map GQ-668, scale 1:24,000. 1968b, Geologic map of the Holy Joe Peak quadrangle, Pinal County, Arizona: U.S. Geol. Survey, Geol. Quad: Map GQ-669, scale 1:24,000.

$1968 \mathrm{c}$, Geologic map of the Lookout Mountain, Pinal County, Arizona: U.S. Geol. Survey, Geol. Quad. Map GQ-670, scale $1: 24,000$.

1968d, Geologic map of the Saddle Mountain quadrangle, Pinal County, Arizona: U.S. Geol. Survey, Geol. Quad. Map GQ-671, scale 1:24,000.

1974a, Geologic quadrangle map of the Winkelman quadrangle, Pinal County, Arizona: U.S. Geol. Survey Geol. Quad. Map GQ-1 106, scale 1:24,000.

1974b, Geologic quadrangle map of the Crozier Peak quadrangle, Pinal County, Arizona: U.S. Geol. Survey Geol. Quad. Map GQ-1 107, scale 1:24,000.

1974d, Geologic quadrangle map of the Putnam Wash quadrangle, Pinal County, Arizona: U.S. Geol. Survey Geol. Quad. Map GQ-1109, scale 1:24,000.

1974, Generalized geology and structure of the Winkelman 15-minute quadrangle and vicinity, Pinal and Gila Counties, Arizona, U.S. Geol. Survey Jour. Research, v.2, no.2.

Krieger, M.H., Cornwall, H.R., and Banks, N.G., 1973, The Big Dome Formation and revised Tertiary stratigraphy in the Ray-San Manuel area, Arizona: U.S. Geol. Survey Bull. 1394-A (Changes in stratigraphic nomenclature)

Pelletier, J.D., 1957, Geology of the San Manuel mine (Arizona): Mining Eng., v. 9, no. 7, p. 760-762.

Peterson, N.P., 1938, Geology and ore deposits of the Mammoth mining camp area, Pinal County, Arizona: Arizona Bur. Mines Bull. 144, geol. ser. 11 (Arizona Univ. Bull., v. 9, no. 2), 63 p. 
Ransome, F.L., 1903, Geology of the Globe copper district, Arizona: U.S. Geol. Survey Prof. Paper 21, $168 \mathrm{p}$.

1919, The copper deposits of Ray and Miami, Arizona: U.S. Geol. Survey Prof. Paper 115, 192 p.

Shride, A.F., 1967, Younger Precambrian Geology in Southern Arizona: U.S. Geol. Survey Prof. Paper $566,89 \mathrm{p}$.

Silver, L.T., 1960, Age determinations on Precambrian diabase differentiates in the Sierra Ancha, Gila County, Arizona [abs.]: Geol. Soc. America Bull., v. 17, no. 12 , pt. 2 , p. 1973-1974.

1968, Precambrian batholiths of Arizona [abs.]: Geol. Soc. America, Cordilleran Sec., 64th. Ann: Mtg., Tucson, Ariz., Program, p. 109-110.

Willden, Ronald, 1964, Geology of the Christmas quadrangle, Gila and Pinal Counties, Arizona: U.S. Geol. Survey Bull. 1161-E, p. E1-E64. 